\title{
Analisis Komparatif Model Altman Z-Score, Springate, Zmijewski Sebagai Alat Ukur Potensi Kebangkrutan
}

\author{
Joni Hendra ${ }^{1}$, Tatik Amani ${ }^{2}$ \\ Universitas Panca Marga ${ }^{1,2}$
}

\begin{abstract}
The study was conducted with the aim to determine the effective measurement of bankruptcy by comparing the Altman (Z-Score), Springate, and Zmijewski methods in the Consumer Goods Industry listed on the Indonesia Stock Exchange (IDX) in 2016 - 2018. This type of research is quantitative, with the variable bankruptcy, Altman (Z-Score), Springate, and Zmijewski. This type of research is quantitative, with the variable bankruptcy, Altman (Z-Score), Springate, and Zmijewski. The population of this study is the Consumer Goods Industry subsector food and beverages with sample selection using purposive sampling so that eleven companies are obtained that meet the sample criteria. The results showed that the calculation results from the Altman Z-Score method were supported by the Springate method because most of them showed relatively similar results. As for the Zmijewski method, the calculation results tend to be different from the other two methods. This can be seen from all companies that are in a safe condition, while the Altman and Springate methods, there is one company that has been declared bankrupt for three periods, namely PT Tri Banyan Tirta Tbk.
\end{abstract}

Keywords: Altman, Springate, Zmijewski, Bankruptcy

\section{Pendahuluan}

Tantangan bagi perusahaan yang masuk dalam industri pada akhir-akhir ini semakin terbuka dan meningkat, tetapi setiap tahunnya persaingan bisnis pun semakin ketat, dimana dikutip dari kompas.com (Selasa, 30 Oktober 2018). Terutama pada sub sektor makanan dan minuman pada Industri Consumer Goods mengalami peningkatan dan pertumbuhan apabila dibandingkan dengan sub sektor lainnya. Meningkatnya pertumbuhan industri ini dari waktu kewaktu mengakibatkan sub sektor ini menjadi peranan penting bagi pertumbuhan ekonomi di Indonesia. Mengingat semakin banyaknya jumlah pertumbuhan penduduk di Indonesia, maka kebutuhan akan makanan dan minuman juga akan meningkat. Meningkatnya kebutuhan masyarakat akan makanan dan minuman, 
maka akan bermunculan industri baru di sektor terkait. Semakin banyak industri baru di sektor makanan dan minuman maka tingkat persaingan antar industri semakin kuat. Dengan semakin kuatnya persaingan ini akan menuntut perusahaan untuk mempertahankan perusahaannya dengan menciptakan keunggulan dan produk yang lebih berkualitas sehingga mampu bersaing dengan perusahaan lain. Jika suatu perusahaan tidak mampu mempertahankan perusahaan dengan kuatnya persaingan ini, maka kinerja perusahaan akan mengalami penurunan dan apabila tidak segera diatasi akan berpotensi kebangkrutan.

Kebangkrutan merupakan suatu kondisi suatu perusahaan yang mengalami kesulitan keuangan akibat penurunan laba setiap tahunnya. Atau kebangkrutan terjadi karena perusahaan tidak mampu memenuhi kewajibannya pada saat jatuh tempo. Oleh karena itu, agar perusahaan dapat mempertahankan kelangsungan hidupnya, pihak manajemen harus cepat bertindak dalam pengambilan keputusan agar tidak terjadi kebangkrutan pada masa mendatang. Untuk mengatasi terjadinya kebangkrutan, pihak manajemen dapat menganalisis terlebih dahulu laporan keuangan perusahaan supaya tanda - tanda kebangkrutan dapat diketahui lebih awal. Metode atau model yang digunakan dalam mengukur potensi kebangkrutan suatu perusahaan yaitu (Metode Altman (Z - Score), Springate, dan Zmijewski). Ketiga model ini dianalisis lalu dibandingkan sehingga ada kemungkinan diperoleh hasil yang berbeda antara metode yang satu dengan lainnya.

Ketiga model ini juga digunakan dalam menganalisis kinerja keuangan yang mempunyai komponen rasio yang berbeda pula untuk mengukur adanya potensi kebangkrutan suatu entitas. Selain itu juga metode tersebut juga memiliki titik cut off yang berbeda antara ketiga model tersebut,

Dengan adanya perbedaan itu maka akan dapat menjadi pertimbangan metode yang mana yang menunjukkan hasil yang relatif sama, sehingga para pihak yang memiliki kepentingan terhadap perusahaan akan dapat menjadikan model pengukuran potensi kebangkrutan sebagai acuan dalam mengambil keputusan yang tepat.

Adapun tujuan yang hendak dicapai dalam penelitian ini adalah: untuk 
mengetahui pengukuran potensi kebangkrutan secara efektif dengan membandingkan metode Altman (Z - Score), Springate, dan Zmijewski pada Industri Consumer Goods yang terdaftar di Bursa Efek Indonesia (BEI).

\section{Tinjauan Pustaka}

\subsection{Tinjauan Peneliti Sebelumnya}

Penelitian sebelumnya yang menggunakan model prediksi diatas dalam memprediksi kebangkrutan dalam penelitiannya yang berjudul "Analisis Model Altman Dan Model Springate Sebagai Early Warning System Terhadap Kondisi Prediksi Bermasalah Pada Bank Go Publik" (Hasanah, 2015). Hasil penelitiannya mengungkapkan bahwa hasil dari analisis kedua model secara statistik terdapat perbedaan. Dalam penelitian lainnya yang berjudul "Analisis Perbandingan Model Prediksi Kebangkrutan Menggunakan Model Altman Modifikasi, Springate, Zmijewski Dan Grover" (Ilhamdi, Taufik, 2016). Hasil pengujian hipotesis penelitian ini menunjukkan terdapat perbedaan signifikan dengan menggunakan model Altman dan model Springate pada perusahaan properti. "Studi Ko mparatif Model Z-Score Altman, Springate Dan Zmijewski Dalam Mengindikasikan Kebangkrutan Perusahaan Yang Terdaftar Di Bursa Efek Indonesia, hasil penelitianya mengungkapkan bahwa dari ketiga model tersebut menunjukan sigifikasi kuat, namun model Zmijewski merupakan model yang paling tepat dalam mengindikasikan kebangkrutan (Nurcahyanti Wahyu, 2015).

\subsection{Landsan Teori}

\subsubsection{Kebangkrutan}

Menurut Rudianto (2013) "Kebangkrutan merupakan suatu kegagalan perusahaan dalam menjalankan bisnisnya untuk mencapai tujuan”. Kebangkrutan (bankcruptcy) juga dapat diartikan sebagai kondisi dimana perusahaaan tidak mampu lagi dalam memenuhi atau melunasi kewajibannya, (Toto dalam Cristoforus, Sri, dan Yunita, 2014).

Penyebab utama kegagalan suatu perusahaan adalah kurangnya kompeten dari pihak manajemen. Namun penyebab secara umumnya dipengaruhi oleh beberapa faktor lain yang saling berkaitan. Penyebab kegagalan suatu perusahaan dapat disebabkan faktor internal dan faktor eksternal (Mulyawan 2015). Dari 
faktor internal antara lain adalah kurang kompetennya manajemen perusahaan yang akan brpengaruh terhadap kebijakan dan keputusan yang diambil. Kesalahan dalam mengambil keputusan akibat kurang kompetennya manajemen yang dapat menjadi penyebab kegagalan perusahaan, meliputi faktor keuangan maupun non keuangan. Berbagai faktor eksternal dapat menjadi penyebab kegagalan sebuah perusahaan antara lain adalah berbagai hal yang timbul atau berasal dari luar perusahaan dan yang berada diluar kekuasaan atau kendali pimpinan perusahaan atau badan usaha, yaitu kondisi perekonomian cara makro, baik domestik maupun internasional, seperti adanya persaingan yang ketat, berkurangnya permintaan terhadap produk yang dihasilkan, serta turunnya harga-harga dan sebagainya".

Untuk ngatasi masalah tersebut dilakukan alternatif perbaikan keuangan melalui analisis kebangkrutan berdasarkan besar kecilnya permasalahan keuangan yang dihadapi perusahaan. Menurut M. Hanafi Mamduh (2016) "analisis kebangkrutan dilakukan untuk memperoleh

Peringatan awal kebangkrutan (tanda-tanda awal kebangkrutan)". Semakin awal tanda tanda kebangkrutan tersebut, semakin baik bagi pihak manajemen bias melakukan perbaikan-perbaikan.

\subsubsection{Model Altman Z-Score}

Perkembangan model yang dikembangkan oleh Altman adalah rumus ZScore pertama dihasilkan Altman pada tahun 1968 (Rudianto, 2013), adalah sebagai berikut:

$$
\mathrm{Z}=1,2 \mathrm{X}_{1}+1,4 \mathrm{X}_{2}+3,3 \mathrm{X}_{3}+0,6 \mathrm{X}_{4}+1,0 \mathrm{X}_{5}
$$

Dimana

X1 : Modal Kerja / Total Aset

X2 : Laba Ditahan / Total Aset

X3 : EBIT / Total Aset

X4 : Nilai Pasar Saham / Total Utang

X5 : Penjualan / Total Aset

Hasil perhitungan dengan menggunakan rumus Z-score tersebut akan menghasilkan skor yang berbeda antara suatu perusahaan dengan perusahaan 
lainnya. Skor yang dihasilkan akan dibandingkan dengan standar penilaian berikut ini untuk menilai keberlangsungan hidup perusahaan:

Jika nilai Z > 2,99 = Zona Aman.

Jika nilai $1,8<\mathrm{Z}<2,99=$ Zona Abu-abu

Jika nilai $\mathrm{Z}<1,8=$ Zona Berbahaya

Rumus ini dihasilkan dari penelitian atas berbagai perusahaan industri di Amerika Serikat yang menjual sahamnya di bursa efek. Karena itu, rumus tersebut lebih cocok digunakan untuk memprediksi keberlangsungan usaha perusahaan manufaktur yang go public".

\subsubsection{Model Springate}

Springate Score dihasilkan oleh Gordon L. V. Springate pada tahun 1978 sebagai pengembangan dari altman Z - Score. Model Springate merupakan model rasio yang memakai multiple discriminate analysis (Rudianto 2013). Dalam model ini menekankan pada profitabilitas sebagai komponen yang paling terpengaruh terhadap kebangkrutan. Rumus dari model ini adalah sebagai berikut :

$$
Z=1,03 X_{1}+3,07 X_{2}+0,66 X_{3}+0,40 X_{4}
$$

Dimana:

$\mathrm{X}_{1}=$ Working Capital/Total Asset

$\mathrm{X}_{2}=\mathrm{EBIT} /$ Total Asset

$\mathrm{X}_{3}=\mathrm{EBT} /$ Current Liability

$\mathrm{X}_{4}=$ Sales/Total Asset

Kriteria analisis untuk menilai keberlangsungan suatu perusahaan adalah sebagai berikut:

$\mathrm{Z}>0,862=$ Perusahaan dalam kondisi Sehat

$\mathrm{Z}<0,862=$ Perusahaan berpotensi bangkrut

\subsubsection{Model Zmijewski}

Mark Zwijewski juga melakukan penelitian untuk meprediksi keberlangsungan hidup sebuah badan usaha. Dari hasil penelitiannya Zmijewski menghasilkan rumus yang bisa dipakai untuk memprediksi potensi kebangkrutan perusahaan disebut sebagai Zmijewski Score (Subramanyam, 2014). Model ini dihasilkan oleh Zmijewski pada tahun 1984 sebagai pengembangan dari berbagai model 
yang telah ada sebelumnya. Hasil penelitian tersebut menghasilkan rumus Zmijewski score untuk berbagai jenis perusahaan, seperti berikut :

$$
Z=-4,3-4,5 X_{1}+5,7 X_{2}-0,004 X_{3}
$$

Dimana:

$\mathrm{X}_{1}=$ Laba Bersih : Total Aset

$\mathrm{X}_{2}=$ Total Hutang : Total Aset

$\mathrm{X}_{3}=$ Aset Lancar : Hutang Lancar

Kriteria analisis untuk menilai keberlangsungan suatu perusahaan adalah sebagai berikut:

$\mathrm{Z}$ bernilai negatif $=$ Perusahaan tidak berpotensi bangkrut

$\mathrm{Z}$ bernilai positif $=$ Perusahaan berpotensi bangkrut

\subsection{Kerangka Konseptual}

Industri Consumer Goods pada sub sektor makanan dan minuman merupakan perusahaan manufaktur yang terdaftar di Bursa Efek Indonesia (BEI) setiap tahun menerbitkan laporan keuangan yang dibutuhkan oleh investor, pemegang saham, analis pasar modal, manajer, karyawan, instansi pajak, pemberi dana (kreditur), dan supplier karena hal ini penting didalam memberikan informasi yang diinginkan oleh para penggunanya dalam kepentingan bisnis untuk menghasilkan laba. Dari laporan keuangan perusahaan dapat diperoleh informasi tentang kinerja perusahaan, apakah perusahaan tersebut memiliki kinerja keuangan yang baik atau tidak. Terdapat 13 (tigabelas) perusahaan industry makanan dan minuman yang akan di analisis dengan metode Altman Z-Score, Springate, dan Zmijewski untuk mengukur potensi kebangkrutan. Nilai Z - Score setiap metode akan disesuaikan dengan kriteria masing - masing metode yang menilai keberlangsungan hidup (going concern) perusahaan. hasil kesimpulan yang diperoleh kemungkinan berbeda beda untuk masing-masing meto de. Dengan hasil yang diperoleh berbeda antara satu metode dengan metode lainnya, maka dapat dipertimbangkan dengan melihat metode yang menunjukkan hasil yang relatif sama. Sehingga hasil akhir penelitian ini akan terlihat apakah perusahaan tersebut mengalami kebangkrutan atau tidak. Berdasarkan deskripsi tersebut, dapat digambarkan kerangka penelitian sebagai berikut: 


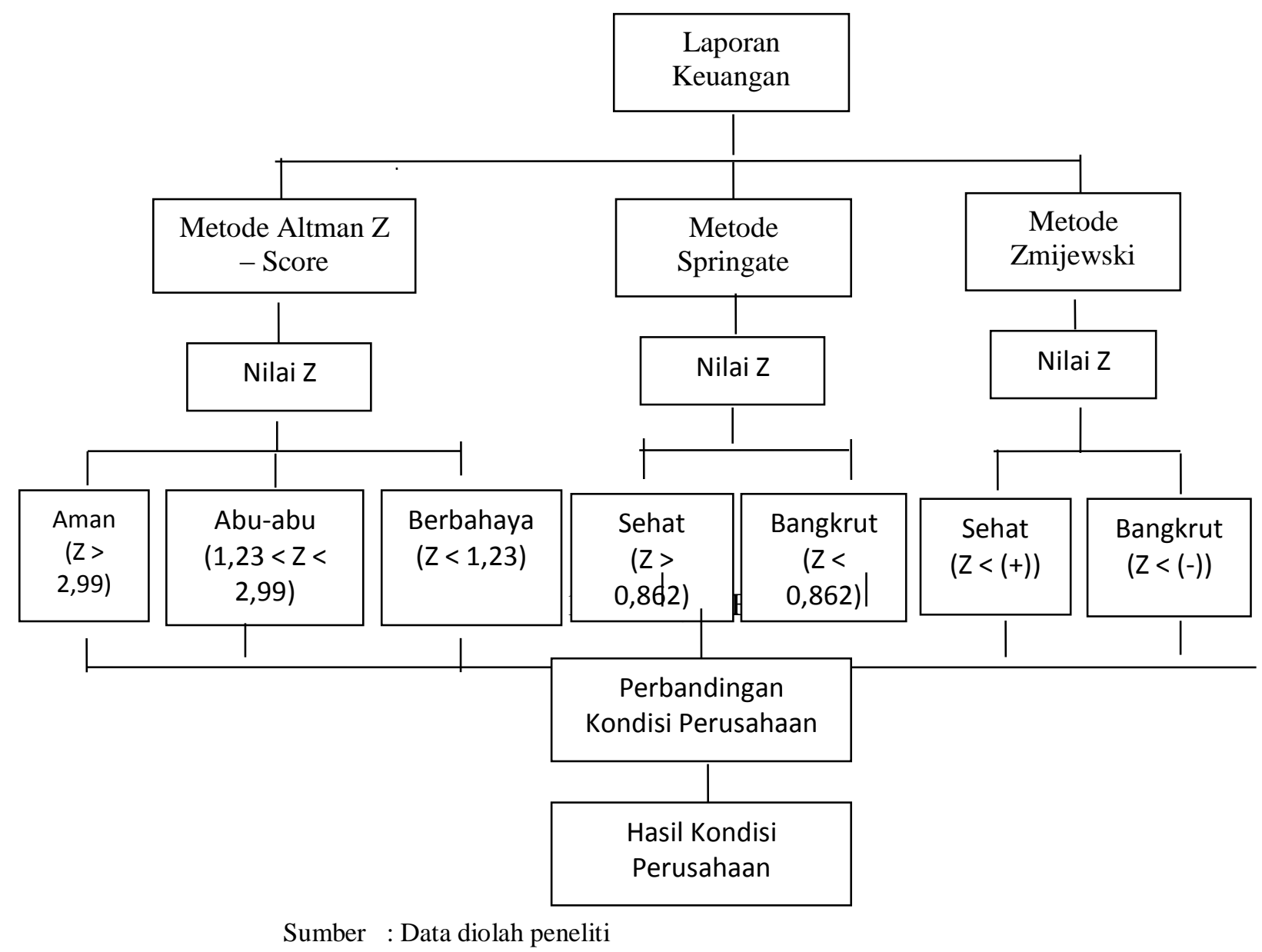

\section{Metode Penelitian}

Jenis penelitian yang digunakan dalam penelitian ini, yaitu penelitian komparatif dengan pendekatan kuantitatif. Menurut Sujarweni (2015) "Penelitian komparatif adalah penelitian yang bersifat membandingkan variabel yang satu dengan variabel yang lain atau variabel satu dengan standar”. Sedangkan Pendekatan kuantitatif merupakan penelitian dengan menggunakan data berupa angka dan analisis yang digunakan statistik, (Sugiyono, 2015: 7).

Metode yang digunakan dalam menganalisis data adalah dengan menggunakan Metode Altman Z-Score Sp ringate, dan Swijewki dengan tahapan sebagai berikut: 
1. Melakukan perhitungan rasio keuangan pada sampel penelitian sesuai dengan variabel yang mengukur potensi kebangkrutan.

2. Menghitung nilai Z-Score pada masing masing perusahaan dalam tahun tertentu dengan modeenggunakan model Altman, Springate, dan Swijewski.

3. Mengklasifikasikan kondisi perusahaan sesuai dengan titik cut off.

4. Membandingkan hasil kondisi perusahaan dengan ketiga metode tersebut yaitu Altman Z - Score, Springate, dan Swijewki. Dengan menggunakan ketiga metode analisis tersebut, hasil kesimpulan yang diperoleh kemungkinan berbeda beda untuk masing-masing metode. Dengan hasil yang diperoleh berbeda antara satu metode dengan metode lainnya, maka dapat dipertimbangkan dengan melihat metode yang menunjukkan hasil yang relatif sama.

\section{Hasil Dan Pembahasan}

\subsection{Perhitungan $Z$ score dengan model Altman, Springate, dan Swijewski}

Hasil analisis keuangan perusahaaan dengan metode Altman Z - Score untuk periode 2016 - 2018 dapat lihat pada tabel 1 berikut ini,

Tabel 1. Hasil Perhitungan Rumus Altman Z - Score Periode 2016-2018

\begin{tabular}{|c|c|c|c|c|}
\hline \multirow{2}{*}{ No } & \multirow{2}{*}{ Perusahaan } & \multicolumn{3}{|c|}{ Altman } \\
\hline & & 2016 & 2017 & 2018 \\
\hline \multirow{2}{*}{1} & \multirow{2}{*}{$\begin{array}{l}\text { PT. Tri Banyan Tirta } \\
\text { Tbk }\end{array}$} & 0,681 & 0,752 & 0,681 \\
\hline & & Berbahaya & Berbahaya & Berbahaya \\
\hline \multirow[b]{2}{*}{2} & \multirow{2}{*}{$\begin{array}{l}\text { PT. Wilmar Cahaya } \\
\text { Indonesia Tbk }\end{array}$} & 5,649 & 5,507 & 7,567 \\
\hline & & Aman & Aman & Aman \\
\hline \multirow{2}{*}{3} & \multirow{2}{*}{ PT. Delta Djakarta Tbk } & 16,461 & 14,744 & 14,567 \\
\hline & & Aman & Aman & Aman \\
\hline \multirow[b]{2}{*}{4} & \multirow{2}{*}{$\begin{array}{l}\text { PT. Indofood CBP } \\
\text { Sukses Makmur Tbk }\end{array}$} & 8,426 & 8,121 & 8,796 \\
\hline & & Aman & Aman & Aman \\
\hline \multirow{2}{*}{5} & \multirow{2}{*}{$\begin{array}{l}\text { PT. Indofood Sukses } \\
\text { Makmur Tbk }\end{array}$} & 2,711 & 2,591 & 2,237 \\
\hline & & Abu-Abu & Abu-Abu & Abu-Abu \\
\hline \multirow[b]{2}{*}{6} & \multirow{2}{*}{$\begin{array}{l}\text { PT. Multi Bintang } \\
\text { Indonesia Tbk }\end{array}$} & 13,829 & 16,125 & 15,307 \\
\hline & & Aman & Aman & Aman \\
\hline \multirow{2}{*}{7} & \multirow{2}{*}{ PT. Mayora Indah Tbk } & 6,392 & 6,656 & 6,911 \\
\hline & & Aman & Aman & Aman \\
\hline \multirow[b]{2}{*}{8} & \multirow{2}{*}{$\begin{array}{l}\text { PT. Nippon Indosari } \\
\text { Corporindo Tbk }\end{array}$} & 5,454 & 4,160 & 4,545 \\
\hline & & Aman & Aman & Aman \\
\hline
\end{tabular}




\begin{tabular}{|c|l|c|c|c|}
\hline \multirow{2}{*}{ No } & \multicolumn{1}{|c|}{ Perusahaan } & \multicolumn{3}{|c|}{ Altman } \\
\cline { 3 - 5 } & \multirow{2}{*}{9} & $\mathbf{2 0 1 6}$ & $\mathbf{2 0 1 7}$ & $\mathbf{2 0 1 8}$ \\
\hline \multirow{2}{*}{10} & \multirow{2}{*}{ PT. Sekar Bumi Tbk } & 2,583 & 2,901 & 2,513 \\
\cline { 3 - 5 } & \multirow{2}{*}{11 Abu-Abu } & Abu-Abu & Abu-Abu \\
\hline \multirow{2}{*}{11} & $\begin{array}{l}\text { PT. Ultrajaya Milk } \\
\text { Industry and Trading } \\
\text { Company Tbk }\end{array}$ & 2,430 & 3,334 & 3,729 \\
\cline { 3 - 5 } & Abu-Abu & Aman & Aman \\
\cline { 3 - 5 } & 13,944 & 12,272 & 14,992 \\
\hline
\end{tabular}

Sumber: Data diolah peneliti

Berdasarkan dari hasil penelitian, telah dijelaskan hasil dari perhitungan rasio Altman Z-Score dan hasil dari perhitungan Altman Z-Score. Hasil perhitungan metode Z-Score Altman menunjukkan terdapat satu perusahaan yang berpotensi bangkrut, tujuh perusahaan aman, dua perusahaan rawan bamgkrut dan satu perusahaan lainnya berpotensi dari rawan bangkrut hingga tidak bangkrut.

Perusahaan dengan hasil pengukuran yang berpotensi berbahaya adalah PT. Tri Banyan Tirta Tbk (ALTO). Perusahaan ALTO tersebut menunjukkan hasil Z-Score kurang dari 1,81. Oleh karena itu, perusahaan tersebut dikategorikan dalam kondisi yang berpotensi bangkrut. Selain itu, kondisi keuangan perusahaan tersebut rata-rata menunjukkan kondisi yang kurang baik, bahkan sebagian besar memiliki modal kerja yang negatif, saldo laba yang negatif, EBIT yang negatif, dan penjualan yang cenderung fluktuatif. Sehingga menyebabkan hasil perhitungan rasio yang fluktuatif selama tiga tahun penelitian.

Sedangkan untuk perusahaan yang tidak berpotensi bangkrut menunjukkan hasil Z-Score lebih dari 2,99. Pada sub sektor makanan dan minuman, perusahaan yang menunjukkan hasil Z-Score tidak berpotensi bangkrut yaitu PT. Wilmar Cahaya Indonesia Tbk, PT. Delta Djakarta Tbk, PT. Indofood CBP Sukses Makmur Tbk, PT. Multi Bintang Indonesia Tbk, PT. Mayora Indah Tbk, PT. Nippon Indosari Corporindo Tbk, PT. Ultrajaya Milk Industry Tbk. Secara keseluruhan, perusahaan tersebut menunjukkan kondisi keuangan yang cukup baik. Sehingga, dapat mempertahankan kondisi yang tidak berpotensi bangkrut atau aman selama tiga tahun penelitian. Selain itu, PT. Sekar Laut Tbk menunjukkan hasil pengukuran dari berpotensi rawan bangkrut hingga tidak 
bangkrut atau aman. Hal itu berarti PT. Sekar Laut Tbk mampu memperbaiki kondisi keuangannya sehingga tidak berpotensi rawan bangkrut di dua tahun terakhir penelitian. Kemudian PT. Indofood Sukses Makmur Tbk dan PT. Sekar Bumi Tbk menunjukkan hasil pengukuran dengan kondisi rawan bangkrut karena memiliki nilai Z sebesar 2,711; 2,591; 2,231 untuk PT. Indofood Sukses Makmur Tbk dan 2,583; 2,901; 2,513 untuk PT. Sekar Bumi Tbk, hal ini dapat dikatakan bahwa nilai $\mathrm{Z}$ berada diantara kurang dari 2,99 dan lebih dari 1,8. Meskipun perusahaan tersebut rawan bangkrut tetapi nilai $\mathrm{Z}$ nya lebih mengarah ke kondisi yang aman, dibandingkan dengan kondisi yang berpotensi bangkrut.

Hasil analisis keuangan perusahaaan dengan metode Springate periode 2016 - 2018 dapat dilihat pada tabel 2 berikut ini,

Tabel 2. Hasil Perhitungan Rumus Springate Periode 2016 - 2018

\begin{tabular}{|c|c|c|c|c|}
\hline \multirow{2}{*}{ No } & \multirow{2}{*}{ Perusahaan } & \multicolumn{3}{|c|}{ Springate } \\
\hline & & 2016 & 2017 & 2018 \\
\hline \multirow[b]{2}{*}{1} & \multirow[b]{2}{*}{ PT. Tri Banyan Tirta Tbk } & 0,074 & $-0,243$ & $-0,135$ \\
\hline & & $\begin{array}{l}\text { Potensial } \\
\text { Bangkrut }\end{array}$ & $\begin{array}{l}\text { Potensial } \\
\text { Bangkrut }\end{array}$ & $\begin{array}{c}\text { Potensial } \\
\text { Bangkrut }\end{array}$ \\
\hline \multirow{2}{*}{2} & \multirow{2}{*}{$\begin{array}{l}\text { PT. Wilmar Cahaya } \\
\text { Indonesia Tbk }\end{array}$} & 2,648 & 2,193 & 2,681 \\
\hline & & Sehat & Sehat & Sehat \\
\hline \multirow{2}{*}{3} & \multirow{2}{*}{ PT. Delta Djakarta Tbk } & 3,361 & 3,554 & 3,354 \\
\hline & & Sehat & Sehat & Sehat \\
\hline \multirow{2}{*}{4} & \multirow{2}{*}{$\begin{array}{l}\text { PT. Indofood CBP Sukses } \\
\text { Makmur Tbk }\end{array}$} & 1,827 & 1,778 & 1,757 \\
\hline & & Sehat & Sehat & Sehat \\
\hline \multirow[b]{2}{*}{5} & \multirow{2}{*}{$\begin{array}{l}\text { PT. Indofood Sukses } \\
\text { Makmur Tbk }\end{array}$} & 1,010 & 0,986 & 0,736 \\
\hline & & Sehat & Sehat & $\begin{array}{l}\text { Potensial } \\
\text { Bangkrut }\end{array}$ \\
\hline \multirow{2}{*}{6} & \multirow{2}{*}{$\begin{array}{l}\text { PT. Multi Bintang Indonesia } \\
\text { Tbk }\end{array}$} & 3,066 & 3,269 & 2,836 \\
\hline & & Sehat & Sehat & Sehat \\
\hline \multirow{2}{*}{7} & \multirow{2}{*}{ PT. Mayora Indah Tbk } & 1,819 & 1,815 & 1,797 \\
\hline & & Sehat & Sehat & Sehat \\
\hline \multirow[b]{2}{*}{8} & \multirow{2}{*}{$\begin{array}{l}\text { PT. Nippon Indosari } \\
\text { Corporindo Tbk }\end{array}$} & 1,794 & 0,803 & 0,900 \\
\hline & & Sehat & $\begin{array}{l}\text { Potensial } \\
\text { Bangkrut }\end{array}$ & Sehat \\
\hline \multirow[b]{2}{*}{9} & \multirow[b]{2}{*}{ PT. Sekar Bumi Tbk } & 0,872 & 0,799 & 0,678 \\
\hline & & Sehat & $\begin{array}{l}\text { Potensial } \\
\text { Bangkrut }\end{array}$ & $\begin{array}{l}\text { Potensial } \\
\text { Bangkrut }\end{array}$ \\
\hline
\end{tabular}




\begin{tabular}{|c|c|c|c|c|}
\hline \multirow{2}{*}{ No } & \multirow{2}{*}{ Perusahaan } & \multicolumn{3}{|c|}{ Springate } \\
\hline & & 2016 & 2017 & 2018 \\
\hline \multirow{2}{*}{10} & \multirow{2}{*}{ PT. Sekar Laut Tbk } & 0,963 & 0,949 & 0,962 \\
\hline & & Sehat & Sehat & Sehat \\
\hline \multirow{2}{*}{11} & \multirow{2}{*}{$\begin{array}{l}\text { PT. Ultrajaya Milk Industry } \\
\text { and Trading Company Tbk }\end{array}$} & 2,677 & 2,290 & 2,280 \\
\hline & & Sehat & Sehat & Sehat \\
\hline
\end{tabular}

Sumber: Data diolah peneliti

Hasil dari perhitungan rasio Springate dan juga perhitungan Springate, dapat diketahui bahwa terdapat satu perusahaan yang berpotensi mengalami kebangkrutan selama tiga periode. Perusahaan tersebut menunjukkan nilai $\mathrm{Z}$ kurang dari 0,862 yaitu PT. Tri Banyan Tirta Tbk. Apabila dilihat dari kondisi keuangan perusahaan, perusahaan tersebut memiliki kondisi keuangan yang kurang baik, bahkan ada yang menunjukkan angka negatif pada modal kerja dan laba serta penjualan yang cenderung fluktuatif. Sehingga menyebabkan nilai rasio perusahaan kurang baik.

Sedangkan untuk perusahaan yang tidak berpotensi bangkrut yaitu PT. Wilmar Cahaya Indonesia Tbk, PT. Delta Djakarta Tbk, PT. Indofood CBP Sukses Makmur Tbk, PT. Multi Bintang Indonesia Tbk, PT. Mayora Indah Tbk, PT. Sekar Laut Tbk, PT. Ultrajaya Milk Industry Tbk. Kondisi kinerja keuangan dari perusahaan tersebut menunjukkan kondisi yang cukup baik, sehingga dengan mengkombinasikan rumus Springate dapat diperoleh hasil nilai Z lebih dari 0,862 yang berarti perusahaan tidak berpotensi bangkrut. Selain itu, PT. Indofood Sukses Makmur Tbk dan PT. Sekar Bumi Tbk menunjukkan hasil pengukuran dari berpotensi tidak bangkrut hingga berpotensi bangkrut, hal ini berarti perusahaan tersebut kurang mampu memperbaiki kinerja keuangannya. Sedangkan PT. Nippon Indosari Corporindo Tbk menunjukkan hasil pengukuran dari berpotensi bangkrut hingga tidak berpotensi bangkrut. Hal itu berarti PT. Nippon Indosari Corporindo Tbk mampu memperbaiki kinerja keuangannya.

Hasil analisis keuangan perusahaaan dengan metode Zmijewski periode 2016 - 2018 dapat dilihat pada table 3 berikut ini, 
Tabel 3. Hasil Perhitungan Zmijewski Periode 2016-2018

\begin{tabular}{|c|c|c|c|c|}
\hline \multirow{2}{*}{ No } & \multirow{2}{*}{ Perusahaan } & \multicolumn{3}{|c|}{ Zmijewski } \\
\hline & & 2016 & 2017 & 2018 \\
\hline \multirow{2}{*}{1} & \multirow{2}{*}{ PT. Tri Banyan Tirta Tbk } & $-0,853$ & $-0,503$ & $-0,457$ \\
\hline & & Sehat & Sehat & Sehat \\
\hline \multirow{2}{*}{2} & \multirow{2}{*}{$\begin{array}{l}\text { PT. Wilmar Cahaya Indonesia } \\
\text { Tbk }\end{array}$} & $-2,946$ & $-2,652$ & $-3,739$ \\
\hline & & Sehat & Sehat & Sehat \\
\hline \multirow{2}{*}{3} & \multirow{2}{*}{ PT. Delta Djakarta Tbk } & $-4,404$ & $-4,439$ & $-4,432$ \\
\hline & & Sehat & Sehat & Sehat \\
\hline \multirow{2}{*}{4} & \multirow{2}{*}{$\begin{array}{l}\text { PT. Indofood CBP Sukses } \\
\text { Makmur Tbk }\end{array}$} & $-2,824$ & $-2,778$ & $-2,984$ \\
\hline & & Sehat & Sehat & Sehat \\
\hline \multirow{2}{*}{5} & \multirow{2}{*}{ PT. Indofood Sukses Makmur Tbk } & $-1,942$ & $-1,900$ & $-1,783$ \\
\hline & & Sehat & Sehat & Sehat \\
\hline \multirow{2}{*}{6} & \multirow{2}{*}{ PT. Multi Bintang Indonesia Tbk } & $-2,601$ & $-3,392$ & $-2,814$ \\
\hline & & Sehat & Sehat & Sehat \\
\hline \multirow{2}{*}{7} & \multirow{2}{*}{ PT. Mayora Indah Tbk } & $-1,856$ & $-1,912$ & $-1,829$ \\
\hline & & Sehat & Sehat & Sehat \\
\hline \multirow{2}{*}{8} & \multirow{2}{*}{$\begin{array}{l}\text { PT. Nippon Indosari Corporindo } \\
\text { Tbk }\end{array}$} & $-1,860$ & $-2,268$ & $-2,529$ \\
\hline & & Sehat & Sehat & Sehat \\
\hline \multirow{2}{*}{9} & \multirow{2}{*}{ PT. Sekar Bumi Tbk } & $-0,802$ & $-2,272$ & $-1,994$ \\
\hline & & Sehat & Sehat & Sehat \\
\hline \multirow{2}{*}{10} & \multirow{2}{*}{ PT. Sekar Laut Tbk } & $-1,739$ & $-1,523$ & $-1,385$ \\
\hline & & Sehat & Sehat & Sehat \\
\hline \multirow{2}{*}{11} & \multirow{2}{*}{$\begin{array}{l}\text { PT. Ultrajaya Milk Industry and } \\
\text { Trading Company Tbk }\end{array}$} & $-4,064$ & $-3,859$ & $-4,085$ \\
\hline & & Sehat & Sehat & Sehat \\
\hline
\end{tabular}

Sumber: Data diolah peneliti

Hasil dari perhitungan rasio dan juga perhitungan Zmijewski, dapat diketahui bahwa semua perusahaan di atas tidak berpotensi bangkrut atau sehat. Perusahaan-perusahaan tersebut memiliki hasil nilai $\mathrm{Z}$ yang negatif selama tiga tahun penelitian, sehingga tidak berpotensi mengalami kebangkrutan.

\subsection{Membandingkan hasil perhitungan Z-Score dari ketiga model yang digunakn (Altman, Springate, dan Swijewki)}

Berdasarkan pengukuran potensi kebangkrutan perusahaan dari masing masing metode menunjukkan hasil yang relatif sama antara metode yang satu dengan metode lainnya. Hal ini dapat dilihat dari hasil perhitungan nilai $\mathrm{Z}$ yang hampir sama untuk ketiga metode tersebut. Selain itu, komponen rasio yang digunakan untuk mengukur potensi kebangkrutannya juga tidak jauh berbeda. 
Metode yang diketahui secara umum dan sejalan dengan peneliti terdahulu diantaranya dalam penelitinnya berjudul analisis perbandingan metode Altman (Z-Score), Springate (S-Score), dan Zmijewski (X-Score) dalam memprediksi kebangkrutan perusahaan (Arum, \& Handayani, 2018), juga dalam penelitiannya berjudul "Analisis Kebangkrutan dengan Menggunakan Model Altman Z-Score pada Perusahaan Makanan dan Minuman yang Terdaftar di Bursa Efek Indonesia (Syakhrun, 2016). Hasil penelitian mereka ini menegaskan bahwa metode Altman Z-Score didukung oleh metode Springate karena sebagian besar menunjukkan hasil yang relatif sama. Sedangkan untuk metode Zmijewski menunjukkan hasil perhitungan yang cenderung berbeda dengan kedua metode lainnya, hal ini dapat dilihat dari semua perusahaan yang berada dalam kondisi sehat, padahal ada perusahaan yang memiliki keuangan yang kurang baik, seperti memiliki modal kerja negatif, laba negatif, EBIT negatif serta penjualan yang cenderung fluktuatif. Selain itu, metode Zmijewski kurang cocok apabila digunakan untuk penelitian ini karena menurut Rudianto metode ini akan lebih akurat apabila digunakan untuk memprediksi perusahaan BEI yang didelisting.

Oleh karena itu, berdasarkan hasil penelitian ketiga metode tersebut, metode yang dapat dijadikan pertimbangan dalam mengambil keputusan oleh pihak yang berkepentingan terhadap perusahaan adalah metode yang menunjukkan hasil relatif sama yaitu metode Altman dan metode Springate. Hasil penelitian ini didukung dengan penelitian yang dilakukan oleh Susanti. Menurut Susanti (2016), "perusahaan yang terdeteksi mengalami kebangkrutan dengan menggunakan metode Altman Z-Score dan Springate, sedangkan metode Zmijewski menjelaskan bahwa ketiga perusahaan dalam keadaan sehat atau terhindar dari kebangkrutan" (112).

Menurut Hendra \& Pujiastuti (2019), “jika penelitian ini hasilnya di prediksi bangkrut tetapi realnya perusahaan tersebut tetap berjalan karena ketiga model hanya sebagai pendeteksi dini terjadinya kebangkrutan dari sisi keuangannya saja, artinya kepastian terjadinya kebangkrutan pada kenyataannya tidak hanya didasari pada laporan keuangan saja tetapi bisa dari bentuk laporan internal perusahaan lainnya" (135). 


\section{Kesimpulan}

Dari hasil analisis data dan pembahasan tersebut maka dapat diambil kesimpulan sebagai berikut: (1) pengukuran potensi kebangkrutan perusahaan dari masing masing metode menunjukkan hasil yang relatif sama antara metode yang satu dengan metode lainnya. Hal ini dapat dilihat dari hasil perhitungan nilai $\mathrm{Z}$ yang hampir sama untuk ketiga metode tersebut. Selain itu, komponen rasio yang digunakan untuk mengukur potensi kebangkrutannya juga tidak jauh berbeda, (2) perusahaan terdeteksi mengalami kebangkrutan dengan menggunakan metode Altman Z-Score dan Springate, sedangkan metode Zmijewski menjelaskan bahwa ketiga perusahaan dalam keadaan sehat atau terhindar dari kebangkrutan.

Sedangkan saran yang dapat dikemukanakan peneliti dalam hal ini adalah (1) bagi perusahaan dan stakeholder, prediksi lebih dini mengenai potensi perusahaan berada dikondisi kesulitan keuangan sangat diperlukan dikarenakan setiap perusahaan memiliki potensi berada pada kondisi financial distress, (2) peneliti selanjutnya diharapkan dapat menciptakan model prediksi potensi financial distress yang baru sehingga penelitian dapat dikembangkan,

\section{DAFTAR PUSTAKA}

Ahmad, Kamarudin. (2017). Dasar-Dasar Manajemen Investasi dan Portofolio. Edisi Revisi. Jakarta : PT Rianeka Cipta.

Arum D P, \& Handayani S R. (2018). Analisis Perbandingan Metode Altman (ZScore), Springate (Sscore), Dan Zmijewski (X-Score) dalam Memprediksi Kebangkrutan Perusahaan (Studi pada Perusahaan Tekstil dan Garmen yang Terdaftar di Bursa Efek Indonesia Periode 2012-2016). Jurnal Administrasi Bisnis. 60(1): 109-118.

http://administrasibisnis.studentjournal.ub.ac.id/index.php/jab/article/view/ $\underline{2487}$

Christoforus Sri Yunita, dkk. (2014). Analisis Potensi Kebangkrutan Dengan Menggunakan Metode Altman Z-Score, Springate Dan Zmijewski Pada Industri Perdagangan Ritel Yang Terdaftar Di BEI Periode 2009-2013. 
Jurnal EMBA. 2(4): 364-373.

Halim, Abdul, \& Halim. (2018). Analisis Investasi dan Aplikasinya: Dalam Aset Keuangan dan Aset Riil, Edisi 2. Jakarta Selatan: Salemba Empat

Hanafi M. (2016). Analisis Laporan Keuangan. Edisi 5. Yogyakarta; UPPN STIM YKPN

Hendra, Pujiastuti. (2019). Analisis Laporan Keuangan Dengan Model Springate Score Sebagai Alat Prediksi Kebangkrutan. Prosiding The $5^{\text {th }}$ Seminar Nasional dan Call Paper “ Kebaruan dan Kode Etik Penelitian“. Universitas Muhammadyah Jember.

Husnan, Suad. (2015). Dasar-Dasar Teori Portofolio dan Analisis Sekuritas. Edisi 5. Yogyakarta : UPPN STIM YKPN.

Ilhamdi, Taufik. (2016). Analisis Perbandingan Model Prediksi Kebangkrutan Menggunakan Model Altman Modifikasi, Springate, Zmijewski Dan Grover (Studi Empiris Pada Perusahaan Sub Sektor Perkebunan Yang Terdaftar Di BEI). Diploma thesis, UPT. Perpustakaan Unad. https://jurnalakuntansiupt.co.id.//.

Kadim, \& Sunardi. (2018). Analisis Altman Z-Score Untuk Memprediksi Kebangkrutan Pada Bank Pemerintah (Bumn) Di Indonesia Tahun 20122016. Jurnal Sekuritas. 1(3): 142-156.

Mulyawan, \& Setia. (2015). Manajemen Keuangan. Bandung: CV Pustaka Setia. Hasanah Nur (2015). Analisis Model Altman Dan Model Springate Sebagai Early Warning System Terhadap Kondisi Prediksi Bermasalah Pada Bank Go Publik, Fakultas Ekonomi dan Ilmu Sosial, Universitas Islam Negeri Syarif Hidayatullah. https://Jurkomuin.co.id.//.

Nurcahyanti W (2015) Studi Komparatif Model Z-Score Altman, Springate Dan Zmijewski Dalam Mengindikasikan Kebangkrutan Perusahaan Yang Terdaftar Di BEI, Jurnal Akuntansi Jurnal Akuntansi Vol.3 No.1 (2015) Universitas Padang.

http://ejournal.unp.ac.id/students/index.php/akt/article/view/1625

Rudianto. (2013). Akuntansi Manajemen Informasi untuk Pengambilan Keputusan Strategis. Jakarta: Erlangga 
Subramanyam, K.R. (2014). Analisis Laporan Keuangan, Financial Statement Analysis. Edisi 11. Jakarta Selatan: Salemba Empat.

Sugiyono. (2017). Metode Penelitian Kuantitatif, Kualitatif, dan $R \& D$, Cetakan 22. Bandung: Alfabeta

Sujarweni, V. Wiratna. (2015). Metodologi Penelitian Bisnis dan Ekonomi, Cetakan 1. Yogyakarta: Pustaka Baru Press.

Susanti Nur (2016). Analisis Kebangkrutan dengan Menggunakan Metode Altman Z-score Springate dan Zmijewski pada Perusahaan Semen yang Terdaftar di BEI Periode 2011-2015. Jurnal Aplikasi Manajemen ISSN: 1693-5241, Program Magister Manajemen Universitas Widyatama, Vol 14 Nomor 4 DOI:http://dx.doi.org/10.18202/jam230263 https://jurnaljam.ub.ac.id/index.php/jam/article/view/984

Syakhrun, dkk. (2016). Analisis Kebangkrutan dengan Menggunakan Model Altman Z-Score pada Perusahaan Makanan dan Minuman yang Terdaftar di Bursa Efek Indonesia. Jurnal Ilmiah Bongaya. 25-32. 